\title{
Geographic expansion and intensification of coffee-growing in Costa Rica during the Green Revolution (1950-89): Drivers and outcomes
}

Andrea Montero, Marc Badia-Miró and Enric Tello

KEYWORDS: coffee-growing, Green Revolution, first and secondnature determinants, Costa Rica.

JEL CODES: C50, N56, N57, R11.

7 his article presents fresh improved aggregated data on coffee-growing regional specialization in Costa Rica between the 1950s to the 1980s and discusses the determinants of the expansion of that coffee cropping frontier with a model that combines environmental and geo-economic drivers. The model performs a multiregression analysis that includes agroclimatic, land use, demographic, and market access variables to explain the geographical patterns of expansion and intensification of coffee-growing areas during the deployment of the Green Revolution. The results allow us to characterize the locations and understand the main drivers behind coffee regional specialization. The results confirm that the locations of coffee-growing expansion were conditioned by a dynamic interaction among first and second-nature factors whose importance changed over time within a complex social and agro-ecological fabric that allowed, to some extent, the endurance of functional shaded management in small-scale coffee plantations. 


\section{La expansión e intensificación cafetalera en Costa Rica durante la revolución verde (1950-1989): Factores impulsores y resultados}

\section{PALABRAS CLAVE: cultivo de café, revolución verde, determinan- tes de primera y segunda naturaleza, Costa Rica.}

\section{CÓDIGOS JEL: C50, N56, N57, R11.}

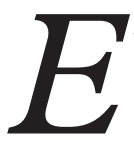

ste artículo presenta nuevos y mejorados datos agregados de la especialización regional del cultivo de café en Costa Rica entre 1950 y 1980. Analiza los determinantes de la expansión de la frontera cafetalera a partir de un modelo que combina factores ambientales y geoeconómicos. El modelo explica los patrones geográficos de expansión e intensificación de las áreas cafeteras durante el despliegue de la revolución verde en función de variables agroclimáticas, de uso del suelo, demográficas y de acceso al mercado. Los resultados permiten identificar los principales factores impulsores de la especialización regional del café. A su vez, confirman que el comportamiento espacial de la expansión cafetalera estuvo condicionado por una interacción dinámica entre factores de primera y segunda naturaleza, cuya importancia cambió a lo largo del tiempo dentro de un complejo tejido socioeconómico y agroecológico que permitió, en cierta medida, la pervivencia del modelo de cultivo bajo sombra en cafetales de pequeña escala.

Received: 2019-02-12 - Revised: 2020-05-11 - Accepted: 2020-03-30

Andrea Montero [orcid.org/0000-0002-7718-9206] is Invited Professor. Address: Department of History, Universidad de Costa Rica, San Pedro de Montes de Oca, 2060 San fosé (Costa Rica). E-mail: andrea.monteromora@ucr.ac.cr

Marc Badia-Miró [orcid.org/0000-0001-5326-1819] is Associate Professor. Address: Departament d'Història Econòmica, Institucions, Política i Economia Mundial, Facultat d'Economia i Empresa, Universitat de Barcelona, Av. Diagonal 690, 08080 Barcelona (Spain). Centre d'Estudis 'Antoni de Capmany' d'Economia i Història Econòmica. Barcelona Economic Analysis Team. E-mail: mbadia@ub.edu

Enric Tello [orcid.org/0000-0002-4970-1524] is Full Professor. Address: Departament d'Història Econòmica, Institucions, Política i Economia Mundial, Facultat d'Economia i Empresa, Universitat de Barcelona, Av. Diagonal 690, 08080 Barcelona (Spain). Centre d'Estudis 'Antoni de Capmany' d'Economia i Història Econòmica. Barcelona Economic Analysis Team.E-mail: tello@ub.edu 


\section{INTRODUCTION}

The Green Revolution inaugurated a new wave of agrarian change in Latin American landscapes that combined both the expansion of the agricultural frontier and the intensification of crops. The new technological package involved the introduction of high-yield varieties, the application of industrial fertilizers and other chemical inputs, and a change in agricultural functional management (Patel, 2013; Swaminathan \& Kesavan, 2017). It was launched in grain crops (corn, wheat, and rice), and then extended to cash crops (Cullather, 2010). Coffee did not escape from this technological package, initially promoted by a favourable price situation during the post-war period (Daviron \& Ponte, 2005; Picado, 2014; Gudmundson, 2014). It was a time when, after oil, coffee became the second most traded legal commodity in the world. Coffee production remains a relevant economic activity. Currently, about 2.25 billion coffee cups are consumed daily, and over 120 million people live off the cultivation of coffee of whom more than 25 million are small producers (Ponte, 2001, 2002; Daviron \& Ponte, 2005).

Latin America remains the most significant coffee growing region in the world, led by Brazil, although Asian and African countries have recently become significant producers. Increased demand during the post-war context led to an improvement in market coffee prices. High prices fostered crop expansion in producing countries as well as the intensification of coffee plantations in line with the Green Revolution. In Colombia, Central America and Mexico coffee intensification meant the transformation from traditional-organic to modern industrial coffee plantations (Moguel \& Toledo, 1999; Rice, 1999; Sfez, 2000; Samper, 2010; Perfecto, Vandermeer \& Philpott, 2014; Infante \& Picado, 2018).

This article draws on previous research conducted by agricultural historians and agricultural economists on the adoption of the Green Revolution package in the coffee sector of Costa Rica in terms of their technical features, political conditioners and results (Hall, 1976; Aguilar, Barboza \& León, 1982; Sfez, 1995, 2000; Samper, 2001; Ledezma \& Granados, 2008; Picado, 2000; Picado, Ledezma \& Granados, 2009; López \& Picado, 2012; Gudmundson, 2014; Infante \& Picado, 2018). It contributes to this literature with new Costa Rican regional series of coffee land uses and yields, which have been rebuilt after noticing the spatial incoherencies of the regionalized data given in some official censuses, and addresses three main geographical and historical questions: How did the coffee frontier expand regionally throughout this period? What drove its geographic specialization pattern over time? And, what have these socio-ecological outcomes meant for the Costa Rican countryside? 
Costa Rica is a relevant case study because it was the first Central American country and one of the first Latin American world regions to promote the Green Revolution on coffee plantations, and achieved the highest coffee productivity per hectare at specific moments of the 1970s (Aguilar, Barboza \& León, 1982; Rice, 1999; López \& Picado, 2012; Infante $\&$ Picado, 2018). Our study adopts a twofold methodological approach. First, we present the stylized facts arising from the new fresh data on the advance of the Costa Rican coffee frontier at the national and regional level. Then, based on the original dataset assembled, we propose a coffee specialization model that statistically testes a set of agroclimatic, land use, demographic, and market access variables to explain coffee-growing area shares in different Costa Rican regions. Finally, we use the data provided and statistical results obtained to discuss its most outstanding socioecological outcomes.

One of our main contributions is to provide a novel dataset of the Utilised Agricultural Area (UAA, meaning all the land used as cropland, pastureland and forest) in different benchmarks (1955, 1963, 1973 and 1984) at the regional level (Central, Western, Turrialba, Tarrazú, Brunca, and Pacific regions). This dataset amends the share of coffee within these UAAs and corrects the overestimation of total land data found in the agricultural censuses of $1955,1963,1973$, and $1984^{1}$. Another relevant finding is to grasp the site-specific environmental, demographic and socioeconomic features of the diverse coffee-growing regions of Costa Rica, by testing the relevance of first-nature factors (i.e., agroclimatic) and second-nature drivers (i.e., market access and labour availability) of the Costa Rican geographic coffee expansion and specialization during the Green Revolution.

Following this introduction, the article is divided into four sections. Section 2 focuses on the institutional coffee context, delving into the main phases of the spread and adoption of the Green Revolution (GR). Section 3 presents the methodology, sources, and data used to test the statistical model. Section 4 shows the main results, and Section 5 concludes.

\section{STATE, MARKET, INSTITUTIONS AND GREEN REVOLUTION DURING COFFEE MODERNIZATION (1950-89)}

In Costa Rica, coffee cultivation began around 1820 in the Central Plateau. It expanded first towards the western region of Alajuela-San Ramón from 1850 to 1860, and then to the eastern Reventazón-Turrialba region from the 1890s onwards (Hall, 1976). The three regions have optimal agroecological conditions for coffee cultivation, although it was in the first area where the population was concentrated. Population density as a driver of la-

1. See Annex 3 at: DOI https://doi.org/10.26882/histagrar.083x04m. 
bour supply is a crucial issue, as coffee cultivation requires plentiful labour during harvest. The expansion to other regions did not mean the closure of prior locations but rather the opening of new coffee-growing areas in separate locations.

Throughout the nineteenth century low population density and the lack of transport infrastructure limited Costa Rican coffee expansion. It was not until the second half of the twentieth century that a favourable economic, political, social, and market context allowed for bringing coffee cultivation outside of traditional regions (Map 1). The construction of the Pan-American Highway connected markets with lands suitable for this crop and pushed the expansion of the Costa Rican coffee frontier. Coffee growing also benefitted from expanding consumption, both in foreign and domestic markets (Jiménez, 1995).

\section{FIGURE 1}

\section{Costa Rican coffee-growing area in hectares (1949-1989)} 120,000

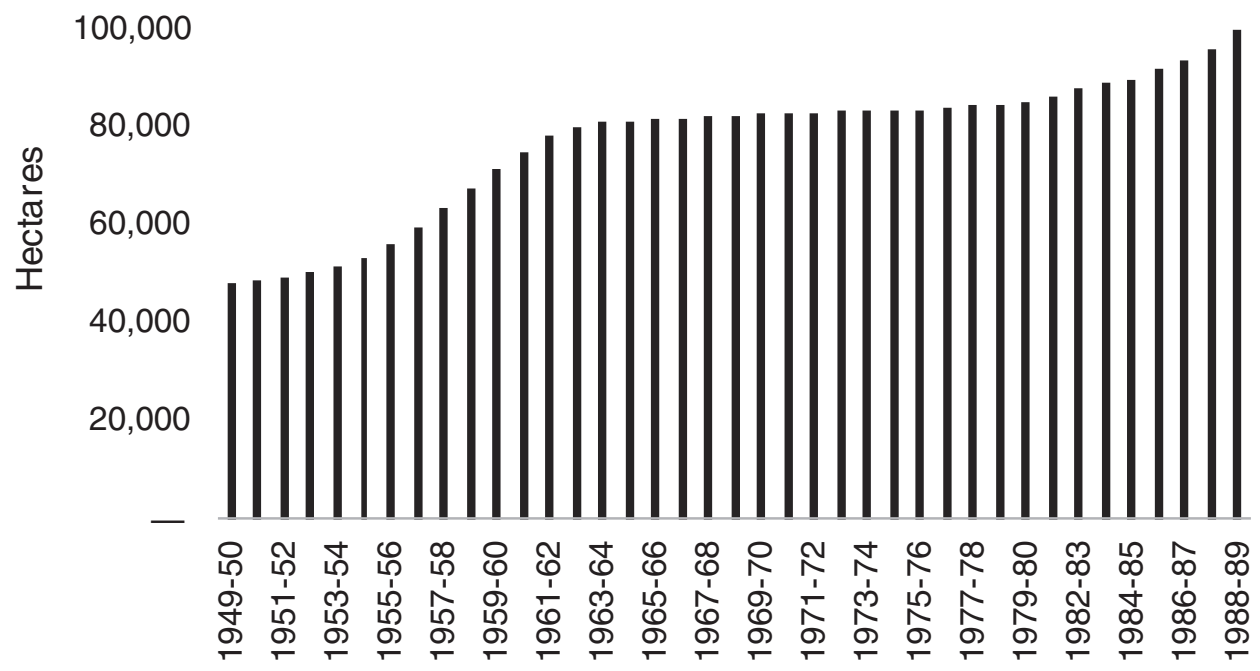

Sources: our own elaboration, from several historical sources.

This favourable external context coincided with a major change at the political and economic level in the country with the start of the Second Republic and the birth of a Developmentalist State, which was led mainly by social-democratic governments (Winson, 1989). The stable institutional policy under this developmentalist governance allowed a strong coffee modernization programme to launch in Costa Rica, inspired by the technological package of the GR, that promoted: a) genetic change, with the introduction of 
high-yielding seeds; $b$ ) technical change, with the implementation of chemical fertilizers and other industrial inputs; and c) cultural change, with the implementation of new agricultural management practices (López \& Picado, 2012; Sfez, 2000).

\section{FIGURE 2}

\section{Costa Rican coffee production in bushels (1949-1989)} $3,000,000$

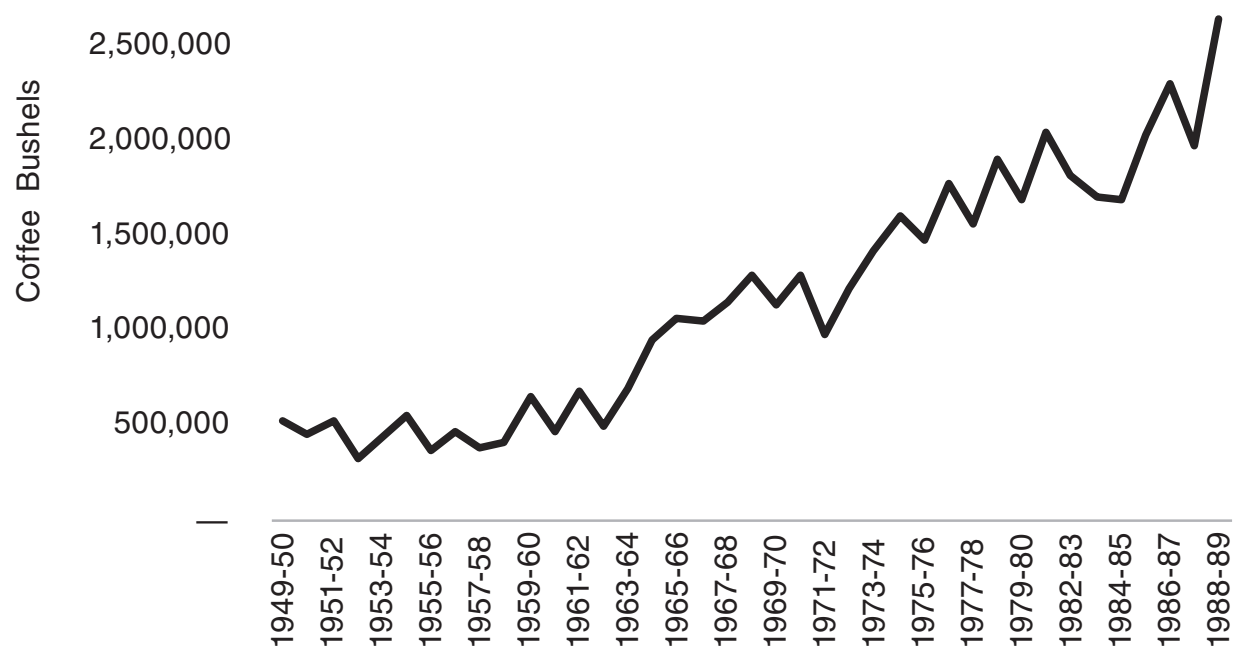

Note: a coffee bushel weighs $258 \mathrm{~kg}$.

Sources: our own elaboration, from several historical sources.

Coffee modernization along GR lines was launched in a period of high prices during the 1940 s and 1950s and spread during a period of coffee price stability in the 1960s. However, as experienced in previous periods of coffee trade growth (Topik \& Samper, 2006), the expansion of global consumption caused an increase of cropland and yields in all coffee producers, leading to global overproduction and a fall in international prices. To prevent significant decreases in coffee prices, most producers and consumers agreed on the ICA (International Coffee Agreement) in 1963, led by the interest of the United States to prevent Soviet influence in Latin America under the Cold War (Topik \& Samper, 2006; Picado, 2012). The ICA restricted world coffee exports through the imposition of quotas and the establishment of a target price by type of coffee (Bilder, 1963; Tilley \& Indahsari, 1996).

During the second half of the twentieth century, Costa Rican coffee activity went through three major phases: 1) production growth by means of substantial crop area expansion $(1948-62) ; 2)$ production growth mainly through productivity growth and small 
crop area expansion (1963-72); and 3) production growth and area expansion of new crop varieties (1972-89) (Figs. 1, 2, and 3). The first phase coincided with the foreign consumption expansion when the coffee market was still more or less liberalized, due to the levelling out of the previous rise in the United States combined with the recovery in the old European markets; the second began when Costa Rica joined the ICA, the international coffee market was regulated, and the domestic market expanded; and the third responded to improving coffee prices because of the Brazilian frost of the 1970s, when the coffee market was still regulated.

FIGURE 3

Costa Rican coffee yield in bushels per hectare (1949-1989) 30.00

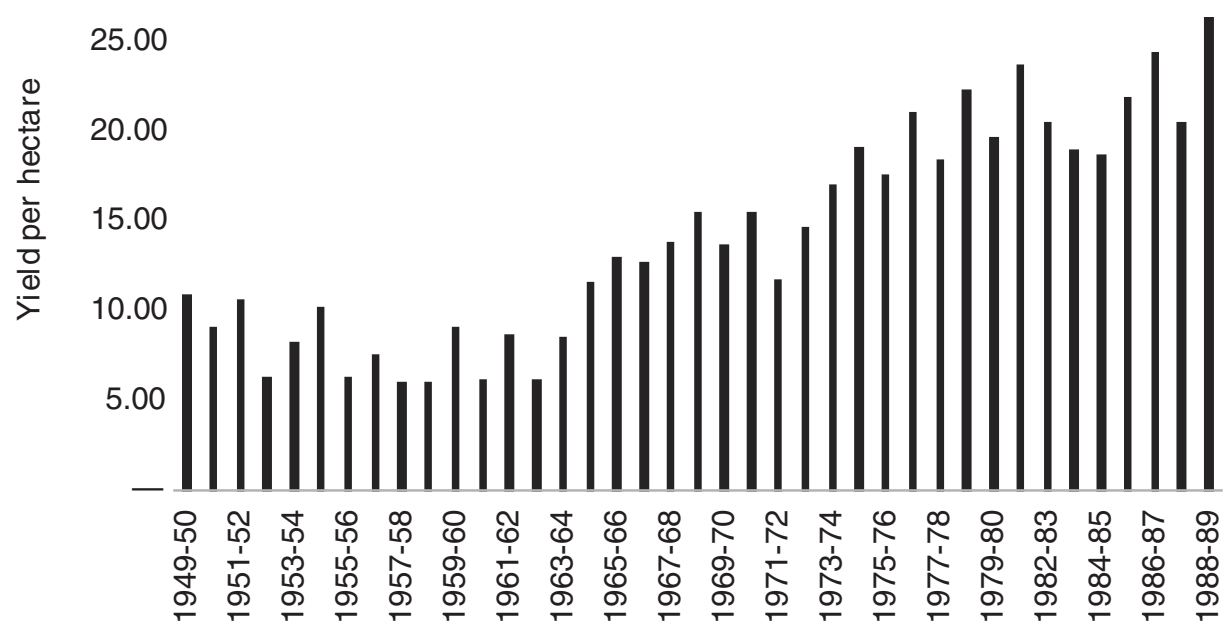

Sources: our own elaboration, from several historical sources.

\subsection{Phases of technology change in Costa Rica's coffee production}

\subsubsection{Take-off (1945-62)}

Until 1950 Costa Rica's farmers produced just one commercial variety of coffee. Since cultivation began around 1820, they had planted Typica coffee (C. arabica), and, from very early on, its qualities were highly appreciated (bean size, cup quality, and good cherryto-green-bean). Although other varieties were tried, only Bourbon gained any real commercial value but cultivation was limited to some mid-altitude areas (800-1200 m). At the end of the 1940s Villa Sarchí coffee emerged as a natural mutation of Bourbon, as Híbrido Tico did from the natural crossing of Typica and Bourbon. 
The Ministry of Agriculture (MAG) launched the Proyecto de Plantas de Alto Rendimiento (High Yield Plant Project) in 1950, and the Programa de Rehabilitación de Cafetales (Coffee Plantation Rehabilitation Program) in 1954. It also promoted a Programa de Selección de Semillas (Seed Selection Program), which consisted mainly of testing the Híbrido Tico variety (MAG, 1954: 218-19; 1957: 11). In 1952 the American Institute for Cooperation on Agriculture (IICA) introduced from Brazil the two high-yielding varieties of Caturra (a natural mutation of Bourbon) and Mundo Novo (a cross between Bourbon and Sumatra), the first of dwarf height and the second of medium height.

During this period, fertilizer imports increased primarily from the United States and Germany. In parallel, the MAG and the National Banking System (SBN) launched the 1953 Plan de Préstamos para Abonos y Fungicidas (Fertilizer and Fungicide Loan Scheme) aimed at promoting industrial fertilization, chemical pesticides, and novel farming practices (MAG, 1955: 5). Experimental trials with macronutrients, such as Nitrogen $(\mathrm{N})$, Phosphorus $(\mathrm{P})$ and Potassium $(\mathrm{K})$, were expanded, as were those with secondary nutrients, such as Calcium (Ca), Magnesium $(\mathrm{Mg})$ and Sulphur $(\mathrm{S})$, and with micronutrients, such as Copper $(\mathrm{Cu})$, Iron $(\mathrm{Fe})$, Zinc $(\mathrm{Zn})$ and Boron (B). Initial findings pointed to the positive effects of industrial fertilizers on increased production, of copperbased fungicides on fighting diseases, and of systemic herbicides and diesel-based emulsions on weed control (MAG, 1955: 3; 1957: 10; 1959: 24).

A series of changes in farming practices were also promoted. Until 1950, the traditional coffee plantation grew Typica coffee under the shade of trees, with densities ranging between 1,200 and 1,500 plants per hectare, and with yields being between 9 and 15 bushels (the coffee bushel equivalent to $258 \mathrm{~kg}$ ) per hectare (Sfez, 2000: 67). New systems of cultivation, pruning, and shade management were recommended. The traditional shadegrown coffee growing had been called into question frequently by agronomists since the late nineteenth century. However, it was impossible to eradicate it from the coffee plantations (Naranjo, 1997; Viales \& Montero, 2015). Moreover, in the face of strong resistance to the adoption of monoculture shown by most Costa Rican coffee producers and family farmers, the cropping systems proposed during this period of the GR-led modernization of the sector included the use of new types of regulated shade. These practices were deemed more commercial, less agrodiverse, and less oriented to family subsistence and the provision of regulation and support ecosystem services (Perfecto \& Vandermeer, 1994; Perfecto et al., 2005; Campbell, 2012). The result was a growth of coffee production and yields, accompanied by an expansion of the cultivated area. 


\subsubsection{Consolidation (1963-71)}

During this phase of worldwide overproduction, the coffee-producing nations came under market regulation. Compared to the earlier period, prices remained low but stable. The IICA abandoned the studies of coffee and concentrated on other crops, but it continued to import high-yielding varieties (HYVs) that were distributed by the MAG. From this time point onwards, research was conducted within the framework of the Coffee Institute of Costa Rica (ICAFE) and the MAG/ICAFE Agreement, and producers had to adapt to the new policy of world coffee regulation of production and exports.

As of 1963, the International Coffee Organization (ICO) obliged its member states to not exceed their production quotas, and to initiate policies of agricultural diversification. In the case of Costa Rica, these measures were incorporated in the 1969 Plan de Politica Cafetalera (Coffee-Growing Policy Plan). In the early sixties, Costa Rican government restricted loans to coffee producers and promoted diversification in regions not optimal for growing coffee (MAG, 1971:56-7). Indeed, quite good prices in the fifties, an open agricultural frontier, and improvements in infrastructure had promoted cultivation in midaltitude areas (Brunca and Pacific regions) which were not always agroecologically suitable. Afterwards, the SBN suspended all loans and raised the interest rate from 6 to $8 \%$ to prevent cultivation in new areas (OFIPLAN, 1979: 1-2).

This phase was marked by the eruptions of the Irazú volcano (March 1963-May 1964), which wreaked havoc in the plantations of the Central Region, the country's main coffee-producing area. The MAG launched the Proyecto de Renovación y Repoblamiento de Plantaciones (Plantation Renewal and Repopulation Scheme) in 1964. Previous studies have tended to ignore this natural event, which contributed to the acceleration of technological change as nearly 24,500 hectares ( $31 \%$ of the country's coffee-producing area) were renewed or repopulated (MAG, 1967: 9). Around this date (1963), Central American Fertilizers (FERTICA) was founded, which in the seventies was to become the most important fertilizer industry in the country. This was also the time when the Catuaí variety was introduced from Brazil.

Research into coffee varieties, industrial fertilizers and farming practices continued. Experimental trials noted an increase in production when the distance between plants was shortened, as opposed to the distance between rows (the greater the number of plants, the greater the yields). Pruning systems were recommended concerning planting densities (MAG, 1970: 143; 1972: 175). Although the use of shade was considered to lower coffee production, experiments also found that full-sun cultivation affected its quality and increased weed control costs (MAG, 1966: 90-1; 1967: 85; 1968: 94). The implementa- 
tion of these GR management practices led to an expansion of the production and productivity through yield increases in a context where the expansion of the cultivated area was very low.

\subsubsection{Dynamization (1972-89)}

A marked hike in coffee prices characterized this phase due to the Brazilian frosts of the 1970s, which led to the suspension of the economic clauses of the ICA until 1980, followed by new price regulations between 1983-86 and 1987-89. The appearance of coffee leaf rust in Brazil also forced the MAG to set up the Comisión Técnica Permanente Asesora contra la Roya (an Advisory Committee against Rust) and to sign the MAG/CATIE contract (CATIE is the The Tropical Agricultural Research and Higher Education Center). From then on, genetic research focused on developing plants that combined adaptability, uniformity, production capacity, rust resistance, and cup quality (MAG, 1979: 567; 1980: 17; 1985: 3).

In Costa Rica, the first outbreak of rust was identified in the canton of San Carlos (1983), from where it quickly expanded to other counties (McCook, 2009, 2017). Research to combat the disease had begun in the early 1970s, and by the end of the decade seed multiplication fields of the more resistant varieties like Geisha T. 2722 and Catimor had been developed and were released for distribution and sale to farmers in 1981 (MAG, 1979: 56-7; 1986: 9).

In 1986, the Programa de Certificación de Semilla y Almácigo de Café (Coffee Seed and Seedbed Certification Program) was launched under the auspices of the Oficina Nacional de Semilla (National Seed Office, ONS). Although improved seed production was a task specifically directed, supervised and executed by agricultural experts from the MAG and ICAFE, the private sector began to sell them without implementing any rigorous controls over their selection and preparation. To monitor seed certification, the Programa de Certificación de Plantas de Almácigo (Seedling Certification Program) was introduced, which meant seedling production had to meet specific quality standards (Vargas, 1986: $11)$.

Research into chemical inputs also underwent a phase of dynamization (MAG, 1973: 92). The soil-plant nutrition program continued to examine fertilizer needs, possible sources of nutrients, the best methods and periods of application of those nutrients, the levels and quantities to use, and their effects on yields and coffee quality. The fertilizer program continued to test different agrochemicals to combat weeds, the best dosages and pe- 
riods for application, the use of different types of equipment, the effects on the crop, and the economic and social advantages and disadvantages of their use (MAG, 1974: 69; 1978: 34; 1979: 101).

In 1978 the Programa Cooperativo para la Protección y Modernización de la Caficultura (Cooperative Programme of Protection and Modernization of Coffee Growing, PROMECAFE) was established as a result of an initiative of USAID (the US foreign assistance agency created by the president John F. Kennedy in 1961) to foster what they named technical coffee production in Latin American countries. A year later, within the framework of PROMECAFE, Costa Rica implemented the Programa de Mejoramiento de la Producción de Café (Program for the Improvement of Coffee Production, PMP) to combat what was considered the low productivity of about $60 \%$ of coffee plantations. The initiative set the target of improving 25,000 hectares of traditional coffee-growing areas ( $30 \%$ of the national coffee area) focusing on small and medium-sized family farms. The PMP was set to be completed in seven years (1980-81 to 1986-87). In the first year, 1,000 hectares were treated, and in the following years, 6,000 hectares were improved along GR lines each year. The PMP opted for HYVs grown in high densities (7,000 trees/ha), although in some areas traditional varieties were recommended. The SBN granted sevenyear loans, the first three years interest-free and then, from the fourth year on, charging a $10 \%$ interest rate (at a time when the yearly Costa Rican inflation rate rose from $18.13 \%$ in 1980 to $53.07 \%$ in 1982 , fell back to $11.97 \%$ in 1984 and was $16.85 \%$ in 1987 , making that interest rate negative in real terms).

\section{METHODOLOGY AND SOURCES}

Our methodology to explain the locations of coffee-growing regions from a geo-economic and agro-ecological point of view advances in two steps. First, we outline the Costa Rican coffee-growing expansion from 1950 to 1980 with new stylized facts obtained from the critical elaboration of the information given in the agricultural censuses (DGEC, 1959, 1965, 1975, 1987) and counties atlases (1950, 1963, 1973 and 1984). As explained in Montero (2018), the inconsistencies found between the figures of the total utilized agricultural area and the aggregation of the extension of all the crops given in these sources have been corrected, which gives rise to new data on coffee specialization by regions and time points (the new data used is given in Annex 3, see note 1).

In both sources, the information is displayed at the level of political-administrative divisions (provinces and counties), and there have been some changes in the political borders at the county level along the four-time points. While the number of provinces re- 
mained stable (seven), the number of counties increased from 65 in 1955 to 81 in 1984 . To carry out our analysis in a way that keeps the coherence of all the regions considered among the time points, we have homogenized the sample in the only feasible manner i. e. according to the spatial borders set in the former territorial division.

Agricultural censuses also provided information on areas devoted to sugarcane and basic grains (corn, beans, and rice) besides coffee. According to the censuses, land use data were grouped and homogenized into five categories: permanent crops (PC), arable crops $(A C)$, pastures $(\mathrm{P})$, forests $(\mathrm{F})$, and other land $(\mathrm{OL})$ not cultivated, which are part of farm units occupied by roads, sidewalks, buildings and other uses. Then we proceeded to calculate the Utilized Agricultural Area (UAA).

$$
\mathrm{UAA}=\mathrm{PC}+\mathrm{AC}+\mathrm{P}+\mathrm{F}-\mathrm{OL}
$$

Accordingly, we estimated the average share of each land use in the UAA, as well as the average area devoted to cultivating coffee, sugarcane, and basic grains, by assuming that coffee expansion was at the expense of the other land-uses. This information allowed us to outline how the growth of the extent of coffee plantations (in hectares) and production (in coffee bushels) affected the development of all the rest of crops and land uses (in hectares) accounted at the regional level and by each intercensal period (1955-63, 1963-73, 1973-84), as well as for all the study period (1955-84). The information obtained was checked also considering the number of coffee farms and coffee production and yields. Demographic data was added and grouped into five categories: total population (TP), male population (MP), female population (FP), rural population (RP), and urban population (UP).

Once the systematization of data was completed, the information was sorted by coffee regions. These are based, with some adjustments, on the ICAFE's coffee regionalization because it responds better to the political-administrative division of the country. In this way, we established six regions of study: Central, Western, Tarrazú, Turrialba, Brunca, and Pacific regions (Annex 1 and Map 1).

Finally, we performed the second methodological step of this research: the entire dataset was used to identify the role of the so called first-nature and second-nature determinants of coffee geographical locations. To that aim, we used a coffee specialization model to explain the historical geography of this process by combining the following agro-ecological and geo-economic driving factors: a) soil and climate; b) land availability and land use; c) demographic variables and labour availability; and d) market access. By specialization we mean the conversion of the regions analysed as relevant parts of the whole Costa 
Rican coffee-growing land turned into an export-oriented cash crop. The model was applied to four time benchmarks in correspondence with the available agricultural censuses. To this dataset, we incorporated agroclimatic data and geographical distances to Costa Rican ports and the capital.

MAP 1

The expansion of coffee-growing frontier during the Green Revolution in Costa Rica, 1950-89

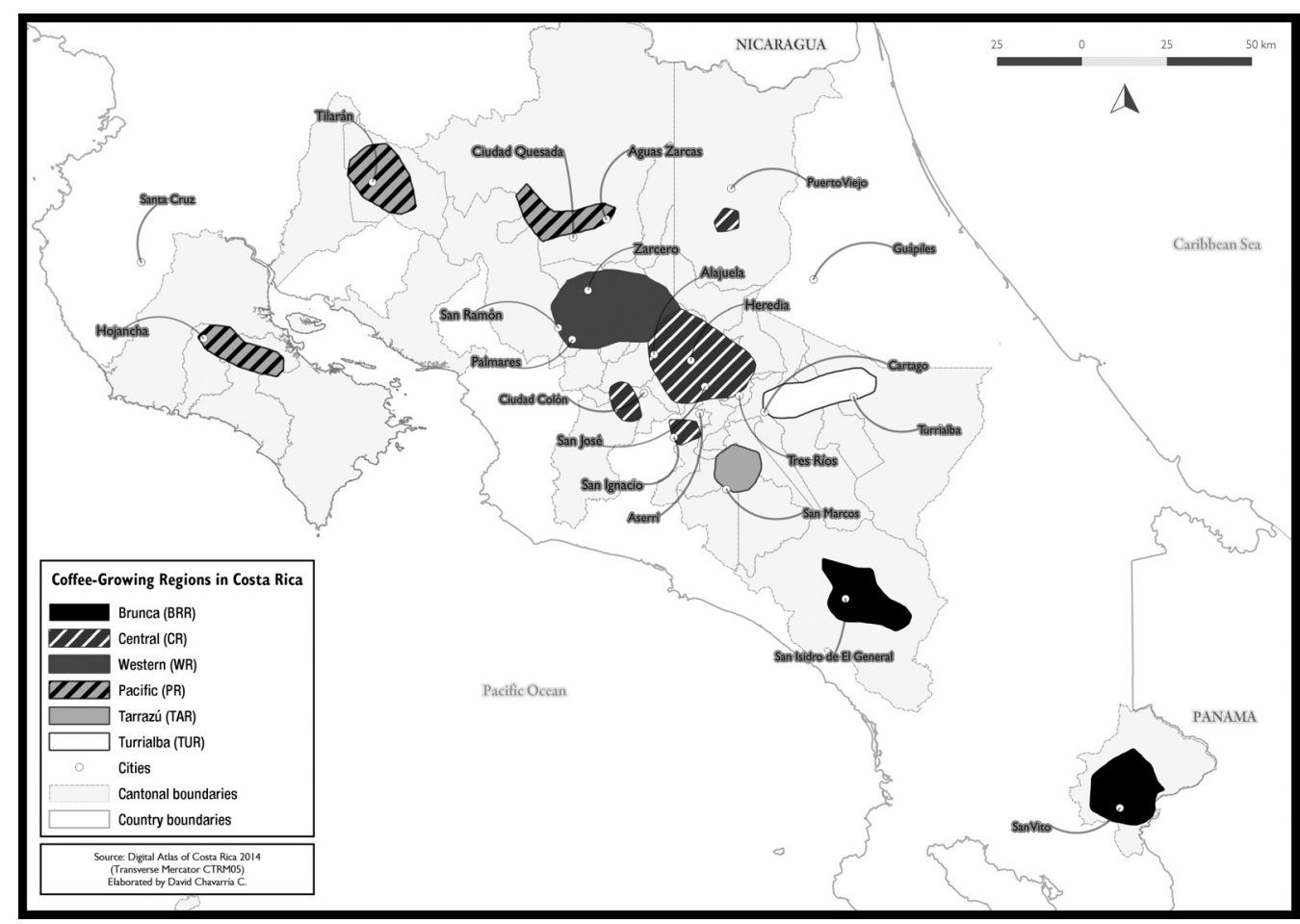

Source: our own elaboration.

Most agroclimatic data were derived from the historical reports of the stations of Instituto Meteorológico Nacional (IMN), the ICAFE, and the Centro de Investigaciones Geofísicas (CIGEFI). The information taken was the average temperature, average rainfall, relative humidity, rainy days, and hours of sunshine. Elevation data were obtained at the district level from the División Territorial Administrativa de Costa Rica (Administrative Territorial Division of Costa Rica) and allowed calculating averages at the county level. Market access was obtained considering the distances of each county to the main seaports (Puerto Limón and Puntarenas), and to the capital. 


\section{RESULTS}

\subsection{Coffee expansion and levels of regional specialization according to the new data on Utilized Agricultural Area: Main stylized facts}

From the 1950s to the 1980s, the Costa Rican coffee area grew from 54,940 hectares to approximately 89,780 hectares (Fig. 1). The first period experienced the most significant increase when around 24,000 hectares were transformed into coffee plantations pulled by the rise in market prices, pushed by a national coffee policy aimed at fostering the adoption of the GR, and allowed by wide land and labour availability. During the second period, expansion slowed down, and only 2,200 hectares were added to the existing coffee agroecosystems, given that yield increases fostered by agrochemicals mainly drove production growth and, when overproduction ensued, the price downturn limited the crop area expansion even more. Finally, in the third period, the Brazilian frost and the recovery of world prices led to an increase in Costa Rican coffee area of approximately 9,000 hectares. As expected, coffee production increased both as a result of coffee area expansion and crop intensification through the GR package (Aguilar, Barboza \& León, 1982; López \& Picado, 2012; Infante \& Picado, 2018). As a result, the country's coffee harvest went from 523,000 coffee bushels in 1955 to 2,200,000 coffee bushels in 1984 (Fig. 2). However, the most considerable production growth coincided with the largest expansion of the coffee-growing area.

The increase in Costa Rican coffee area and production took on different nuances at the regional level (Map 1). The Brunca Region showed the largest area increase (Fig. 4). This expansion could be attributed to several factors: a) the construction of the Pan-American Highway which improved the connection of the region to the domestic and international markets; $b$ ) the relatively optimal agroecological conditions of the region; c) the steady migration flow; and d) the overall increase in the resident population. This region also showed the most significant increase in coffee production (Fig. 5). Between 1955 and 1984, it went from 10,720 to about 307,000 bushels, most of it in the first period. The existing private coffee mills were unable to process this fast increase (Chacón \& Montero, 2015). In 1951 the Banco Nacional de Costa Rica (BNCR) established El General coffee mill, which in a few years absorbed part of the harvest increases and reached its full capacity. In 1962-63 this coffee mill -which a year later became a cooperative- received coffee from 3,500 clients and processed some 35,000 bushels (Raventós, 1986). 
FIGURE 4

\section{Costa Rican coffee area (by regions), 1955-1984}

900,000

800,000

700,000

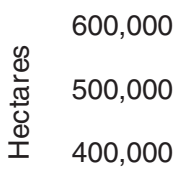

300,000

200,000

100,000

$-$

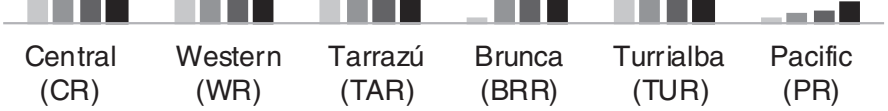

- $1955 \quad 1963 \quad 1973$ - 1984

Sources: own elaboration from agricultural censuses of 1955, 1963, 1973 and 1984.

FIGURE 5

Costa Rican coffee productions (by regions), 1955-1984 35,000

30,000

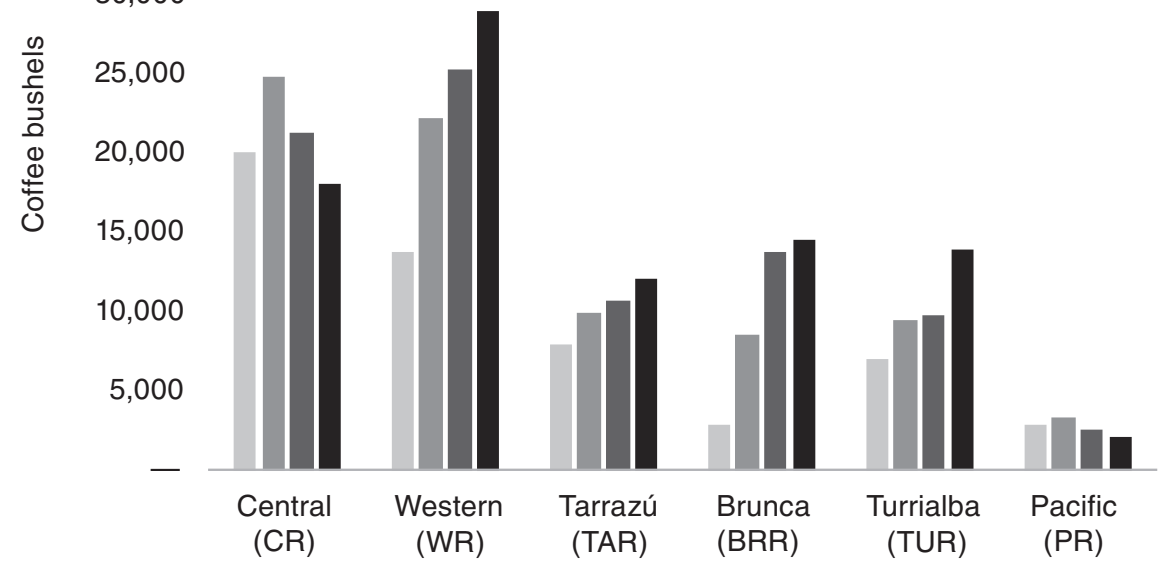

$\square 1955 \square 1963 \quad \square 1973 \quad \square 1984$

Note: a coffee bushel weights $258 \mathrm{~kg}$.

Sources: own elaboration from agricultural censuses of 1955, 1963, 1973 and 1984. 


\section{FIGURE 6}

Costa Rican coffee yields in bushels per hectare (by regions), 1955-1984

30



Sources: own elaboration from agricultural censuses of 1955, 1963, 1973 and 1984. See note 1 and Montero (2018) for detailed data.

TABLE 1

Costa Rican annual growth of coffee area and production by regions and intercensal periods, 1955-1984

\begin{tabular}{lrccccccc}
\hline Regions & \multicolumn{2}{c}{$\mathbf{1 9 5 5 - 6 3}$} & \multicolumn{2}{c}{$\mathbf{1 9 6 3 - 7 3}$} & \multicolumn{2}{c}{$\mathbf{1 9 7 3 - 8 4}$} & \multicolumn{2}{c}{$\mathbf{1 9 5 5 - 8 4}$} \\
\hline & Area & Production & Area & Production & Area & Production & Area & Production \\
\hline Brunca & $14.0 \%$ & $29.4 \%$ & $4.9 \%$ & $9.2 \%$ & $0.5 \%$ & $3.7 \%$ & $5.6 \%$ & $12.2 \%$ \\
Western & $5.3 \%$ & $13.2 \%$ & $1.2 \%$ & $4.5 \%$ & $1.8 \%$ & $4.5 \%$ & $2.6 \%$ & $6.8 \%$ \\
Turrialba & $3.4 \%$ & $16.6 \%$ & $0.2 \%$ & $2.8 \%$ & $3.2 \%$ & $3.7 \%$ & $2.2 \%$ & $6.7 \%$ \\
Tarrazú & $2.8 \%$ & $8.4 \%$ & $0.6 \%$ & $3.4 \%$ & $1.1 \%$ & $5.4 \%$ & $1.4 \%$ & $5.5 \%$ \\
Pacific & $6.2 \%$ & $5.4 \%$ & $-2.6 \%$ & $2.2 \%$ & $0.1 \%$ & $5.7 \%$ & $0.8 \%$ & $4.4 \%$ \\
Central & $2.6 \%$ & $2.6 \%$ & $-2.1 \%$ & $0.3 \%$ & $-0.9 \%$ & $1.7 \%$ & $-0.4 \%$ & $2.4 \%$ \\
\hline Total & $\mathbf{4 . 5} \%$ & $\mathbf{9 . 1} \%$ & $\mathbf{0 . 2} \%$ & $\mathbf{3 . 1} \%$ & $\mathbf{1 . 0} \%$ & $\mathbf{3 . 9} \%$ & $\mathbf{1 . 7} \%$ & $\mathbf{5 . 0} \%$ \\
\hline
\end{tabular}

Source: own elaboration from the agricultural censuses of 1955, 1963, 1973 and 1984 . See note 1 and Montero (2018) for detailed data.

The Western Region was the area with the second-largest increase in coffee-growing surface, which doubled from 1955 to 1984 (Fig. 4). Historically, it had been one of the leading coffee production areas of Costa Rica, but cultivation remained concentrated in sev- 
eral specific counties (Alajuela, Naranjo, and Sarchí) due to the lack of railways that in other countries like Brazil had drove the advance of the coffee-growing frontier (Vidal Luna, Klein \& Summerhill, 2016). It was in the second half of the twentieth century when improvements in transport infrastructure allowed the expansion of the coffee frontier towards other counties (Poás, Alfaro Ruíz, Orotina, and San Mateo). This was also the region with the second-greatest coffee production, which between 1955 and 1984 grew from about 107,700 to 735,620 bushels. The first period recorded the most significant increase fundamentally linked to area expansion, while in the other periods production growth was mainly related to yield increases through technological change (Figs. 5, and 6, and Table $1)$.

The Turrialba Region was also crucial in coffee area expansion. Coffee cropping began in the late nineteenth century in this county, where medium and large properties predominated, despite having to deal with labour shortages (Hall, 1976). After 1950 infrastructure improvements helped to enlarge the cultivated area. Despite showing an increase as a coffee-growing region, the Turrialba Region occupied the penultimate position in Costa Rican coffee production (Fig. 4). Technological change seems to have been gradual there. According to the Census of 1963, most coffee producers (63\%) in this region still had not changed to the HYV recommended by the GR promoters.

The Tarrazú Region, currently one of the country's most important coffee growing regions, was the fourth in experiencing the largest coffee area increase. It rose from about 8,020 to approximately 12,100 hectares from 1955 to 1984 , and growth was also stronger in the first period (Table 1). Expansion can be here explained by several factors: a) the construction of the Pan-American Highway; b) optimal agroecological conditions of these new areas; c) the opening of the agricultural frontier outside traditional coffee-growing regions; and d) population increase which favoured coffee production. The Highway created access to the market for some land, mainly in Los Santos area, with optimal conditions for coffee growing despite being very steep and prone to soil erosion (Picado, 2000; Ledezma \& Granados, 2008). The region also ranked fourth regarding coffee production (Table 1). The technological change was active both in new and traditional zones, while the coffee frontier remained open. In 1960 production expansion allowed the establishment of two coffee mill cooperatives (Coope Tarrazú and Coope Dota) (Picado, Ledezma \& Granados, 2009; Chacón \& Montero, 2015).

Coffee cultivation also expanded in the Pacific Region, but only for a while. Higher prices in the international market led to a kind of "coffee fever" that pushed coffee cultivation to non-optimal areas. During the first period, the coffee-growing area grew at an annual rate of $6.2 \%$, while production increased at an annual rate of $5.4 \%$. In the later 
periods, cultivated area and production fell in most zones (Table 1). Today coffee cultivation in this region is insignificant. After the breakdown of the ICA, most coffee producers of this region changed to new crops such as melon, rice, or to other land uses such as pastures in the 1990s.

The Central Region was the only one with a net area decrease, from around 20,200 to 18,000 hectares, although this did not mean a reduction in coffee production due to the impact of technical change on yields. Between 1955 and 1984, harvests doubled from 249,700 to approximately 496,800 bushels thanks to crop intensification (Fig. 5, and Table 1). We also observe that some lands close to the main cities, formerly devoted to coffee, changed to residential and industrial uses in the context of the Import Substitution Industrialization (ISI) policies and urban sprawl.

The stylized regional facts suggest that the increase in Costa Rican coffee area was closely linked to the dynamics of the international market, and to the existence of an open frontier where coffee cultivation could be expanded. The country went through a coffee expansion and land-use intensification, which was at first directly associated with high coffee prices. This was also possible because of other endogenous factors such as land availability with adequate agroclimatic conditions, growth in transport infrastructures, labour availability and favourable institutional policies.

Population increase as a result of growing birth rates was also one of the pushing factors that favoured coffee-growing expansion. However, its long-term impact differed throughout the different phases of the Costa Rican demographic transition, the increase of urbanization rates, and rural-urban migrations. During a great part of our study period, and despite the increasing migration to the metropolitan area of San José and other cities, the population of Costa Rica could supply most of the workforce that coffee growers needed. But when birth rates declined with the advancement of the demographic transition and urbanization processes, agricultural family labour could provide the permanent workforce throughout the year, but not the increased demand at harvest peaks. Thanks to the existence of different harvest altitudes and seasons between coffee regions of the country, seasonal migrations could supply the necessary coffee pickers from rural and also urban areas of Costa Rica. Only when the country entered the third phase of its demographic transition at the end of the twentieth century did harvesters increasingly have to be recruited from Nicaragua and the Ngöbe indigenous communities on the border with Panama, with relevant impacts on rural inequality.

Regarding its impact on the Costa Rican agricultural landscapes, these coffee regions experienced complex and changing dynamics along different historical moments. Dur- 
ing the intercensal periods analysed here coffee expansion did not necessarily mean coffee predominance. It only became another crop in a varied agricultural landscape that tended towards diversification. Overall, from the 1950s to the 1980s, we observe an expansion in the share of coffee cultivation area over the UAA, although it varied according to different regions and it never became the predominant crop in any Costa Rican region (Table 2)

\section{TABLE 2}

Regional coffee land shares in the UAA (1955-1984)

\begin{tabular}{lcccc}
\hline Regions & $\mathbf{1 9 5 5}$ & $\mathbf{1 9 6 3}$ & $\mathbf{1 9 7 3}$ & $\mathbf{1 9 8 4}$ \\
\hline Tarrazú & $8.95 \%$ & $11.19 \%$ & $11.96 \%$ & $16.17 \%$ \\
Central & $6.23 \%$ & $7.68 \%$ & $7.54 \%$ & $6.51 \%$ \\
Turrialba & $5.63 \%$ & $7.37 \%$ & $6.18 \%$ & $11.32 \%$ \\
Western & $2.74 \%$ & $4.16 \%$ & $4.72 \%$ & $6.23 \%$ \\
Brunca & $0.48 \%$ & $1.38 \%$ & $2.23 \%$ & $2.46 \%$ \\
Pacific & $0.25 \%$ & $0.43 \%$ & $0.31 \%$ & $0.35 \%$ \\
\hline Total & $\mathbf{1 . 6 7 \%}$ & $\mathbf{2 . 3 9 \%}$ & $\mathbf{2 . 4 6 \%}$ & $\mathbf{2 . 9 9 \%}$ \\
\hline
\end{tabular}

Source: own elaboration from the agricultural censuses of 1955, 1963, 1973 and 1984. See note 1 and Montero (2018) for detailed data.

By regions, Tarrazú reports the highest percentage of coffee area, which nearly doubled from 1955 to 1984. In the Central Region, where the cropping area decreased as land was taken over by urban sprawl, coffee remained an important crop in the regional landscape, and in some counties its share was greater than half. In the Western Region, the mosaic pattern of land uses was even more diversified. Historically, coffee had been a complementary crop to sugarcane, but had not replaced it. In Tarrazú coffee gained importance within the UAA after the 1970s, although a landscape mosaic pattern also prevailed (Picado, Ledezma \& Granados, 2009). In the Brunca Region the share of land occupied by coffee grew, but this crop was far from being the most important. Forests, pastures, and basic grains were the land uses that predominated. The Pacific Region figures confirm the limited extent of coffee plantations in the area, where cattle and pastures remained the main agrarian land uses.

During the first period, when the advance of the coffee frontier was greater, in most of the regions area expansion went in parallel to the growth in pastures within a large forest land matrix, meaning only a small reduction in sugarcane cultivation. This means that most of this coffee expansion was the result of an open frontier dynamic. 


\subsection{Main drivers of regional coffee-growing specialization: Model specification, results and discussion}

We tested the determinants of the coffee-growing frontier expansion of Costa Rica from 1950 to 1980 , outlined so far, by considering the following model:

$$
\text { Coffee_Sup }_{j t}=\alpha_{1}+\alpha_{2} \cdot \text { AGRCL }_{j t}+\alpha_{3} \cdot \text { LUSES }_{j t}+\alpha_{4} \cdot M K A C_{j t}+\alpha_{5} \cdot \text { DEN }_{j, t-1}+\varepsilon_{j t}
$$

Where Coffee Sup $j$ is the percentage of proportion of UAA allocated to coffee for each Costa Rican region $j$ in the period $t ; A G C L_{j t}$ are a set of agroclimatic variables that could affect coffee specialization in each region $j$ (constant for the four periods); $L U S E S_{j t}$ is the percentage share of UAA allocated to several lands uses (sugarcane, pastures, forest, and basic grains) complementary or substitutive of coffee plantations for each region $j$ and in the period $t ; M K A C_{j t}$ tries to capture the pull effect through market access (either domestic and foreign) as assessed by distances from the capital of the region $j$ to the seaport and to the capital of the country (constant for the four periods); and $D E N_{j, t}$ refers to population density for each region $j$ and the period $t$.

We apply logarithms for each of the variables and incorporate two sets of dummies: spatial dummies for each region (Central, Western, Tarrazú, Brunca, and Pacific), and time dummies $(1955,1963,1984)$. The main statistics of the variables considered are seen in Table 3.

TABLE 3

Main variable statistics

\begin{tabular}{lccccc}
\hline Variables & Mean & Minimum & Maximum & SD & Unit \\
\hline Coffee-growing area (1) & 0.145 & 4.96 & 0.854 & 0.197 & Percentage \\
Altitude (1) & 851 & 16.4 & 1874 & 532.18 & Meters \\
Sunshine (1) & 5.553 & 4.2 & 7.5 & 0.701 & Hours \\
Rainy days (1) & 188.39 & 125 & 256 & 29.11 & Days \\
UAA sugarcane (2) & 0.018 & 0 & 0.26 & 0.036 & Percentage \\
UAA grains (2) & 0.044 & 0 & 0.28 & 0.045 & Percentage \\
UAA pastures (2) & 0.39 & 0 & 0.87 & 0.195 & Percentage \\
UAA forests (2) & 0.202 & 0 & 0.7 & 0.133 & Percentage \\
Dist. Puerto Limón (3) & 217.10 & 33 & 475 & 96.02 & Kilometres \\
Pop. density (4) & 322.08 & 3.1 & 7079 & 827.56 & Inhabitants/km² \\
\hline
\end{tabular}

Notes: (1) soil and climate; (2) land uses; (3) demographic; and (4) market access.

Source: our own elaboration from the sources indicated in the text. 
After testing this set of variables, the results obtained have confirmed: a) a positive and significant relationship of coffee-growing locations with agroclimatic and environmental variables such as altitude, sunshine and rainy days; b) a negative and significant relationship with pastures; c) a positive and stronger relationship with population density; and d) a negative and significant relationship with the distances to the main port (Puerto Limón), taken as proxy for market access. We run the test for each time point $(1955,1963$, 1973, and 1984) and the whole sample (Table 4).

\section{TABLE 4}

Explaining regional coffee specialization determinants in Costa Rica

\begin{tabular}{|c|c|c|c|c|c|c|}
\hline Variables & $\begin{array}{c}\text { (1) } \\
\text { OLS }\end{array}$ & $\begin{array}{c}\text { (2) } \\
\text { OLS }\end{array}$ & $\begin{array}{c}\text { (3) } \\
\text { OLS }\end{array}$ & $\begin{array}{c}\text { (4) } \\
\text { OLS }\end{array}$ & $\begin{array}{c}(5) \\
\text { TOBIT }\end{array}$ & $\begin{array}{c}(6) \\
\text { TOBIT }\end{array}$ \\
\hline \multirow[t]{2}{*}{ Altitude (Lg) } & $1.134^{\star \star \star}$ & $1.190^{\star \star \star}$ & $1.139^{\star \star \star}$ & $0.891^{\star \star \star}$ & $1.081^{\star \star \star}$ & $1.206^{\star \star \star}$ \\
\hline & $(4.88)$ & $(3.90)$ & (3.96) & (3.12) & (10.22) & $(6.25)$ \\
\hline \multirow[t]{2}{*}{ Sunshine (Lg) } & $3.537^{\star \star *}$ & $3.941^{\star \star \star}$ & 2.518 & 3.095 & $3.560^{* * *}$ & $3.999^{\star \star *}$ \\
\hline & $(2.78)$ & $(2.38)$ & $(1.40)$ & $(1.6)$ & $(3.72)$ & $(2.31)$ \\
\hline \multirow[t]{2}{*}{ Rainy D (Lg) } & $2.123^{\star \star \star}$ & $2.915^{\star \star \star}$ & $3.043^{\star \star \star}$ & $2.689^{\star \star \star}$ & $2.788^{\star \star *}$ & $2.989^{\star \star *}$ \\
\hline & $(2.02)$ & $(2.05)$ & $(2.46)$ & $(2.02)$ & $(3.70)$ & $(2.16)$ \\
\hline \multirow[t]{2}{*}{ Pastures (Lg) } & $-0.630^{* *}$ & $-0.483^{*}$ & -0.400 & $-1.434^{\star * *}$ & $-0.455^{\star \star \star}$ & $-0.485^{\star \star}$ \\
\hline & $(-1.99)$ & $(-1.76)$ & $(-1.22)$ & $(-3.27)$ & $(-3.23)$ & $(-1.81)$ \\
\hline \multirow[t]{2}{*}{ Puerto Limón Dist. (Lg) } & 0.053 & $-0.757^{\star \star}$ & $-0.348^{\star}$ & -0.410 & $-0.492^{\star \star \star}$ & $-0.775^{\star}$ \\
\hline & $(0.14)$ & $(-1.76)$ & $(-0.64)$ & $(-1.03)$ & $(-2.04)$ & $(-1.72)$ \\
\hline \multirow[t]{2}{*}{ Pop. Dens. (Lg) } & $0.966^{\star * *}$ & $0.702^{\star \star \star}$ & $0.549^{\star \star \star}$ & $0.597^{\star \star \star}$ & $0.695^{\star * \star}$ & $0.697^{\star * *}$ \\
\hline & $(5.60)$ & $(5.05)$ & $(4.26)$ & $(3.79)$ & $(10.25)$ & $(5.45)$ \\
\hline \multirow[t]{2}{*}{ Const. } & -32.231 & $-32.766^{\star \star *}$ & -32.007 & $-30.368^{* \star *}$ & $-31.844^{\star \star *}$ & $-33.272^{\star \star \star}$ \\
\hline & $(-4.29)$ & $(-3.20)$ & $(-3.46)$ & $(-3.31)$ & $(-5.87)$ & $(-3.31)$ \\
\hline Observ. & 65 & 65 & 65 & 65 & 260 & 65 \\
\hline $\mathrm{R}^{2}$ & 0.838 & 0.814 & 0.787 & 0.767 & / $\sigma 1.185$ & / 1.077 \\
\hline Spatial D & Yes & Yes & Yes & Yes & Yes & Yes \\
\hline Temporal D & No & No & No & No & Yes & No \\
\hline Year & 1955 & 1963 & 1973 & 1984 & $1955-84$ & 1963 \\
\hline
\end{tabular}

Note: significance t-statistics in brackets. ${ }^{\star \star \star}$ significance at $1 \%$; ${ }^{\star \star}$ significance at $5 \%$; and ${ }^{\star}$ significance at $10 \%$. See note 1 for more detailed results.

Source: our own elaboration, from the data described in the text.

First of all, these results make it apparent that coffee plantations have to be seen as a set of agroecosystems whose location patterns where chosen according to environmental, technical, and socioeconomic factors that continuously interacted in these territories. 
From 1950 to 1980 regional coffee expansion was determined in Costa Rica by the plant agroecological adaptability and its tolerance level to soil and climate conditions that have two extreme points (maximum and minimum), and some optimal values in between. Although it grows in a wide altitudinal span from near sea level up to 1,800 meters, the optimal range is considered to be between 1,000 meters and 1,400 meters. Cultivation is not currently recommended below 600 meters or above 1,600 meters (Hall, 1976; Fournier, 1980). The results confirm that the Costa Rican coffee-growing frontier expanded mainly in those agroecological optimal areas.

The difficulties of expanding coffee plantations outside Costa Rican first-nature optimal regions, together with the ban on planting species other than Arabica, led the country to become a highland coffee producer very early and to keep this feature throughout the years of the GR (Hall, 1976; Naranjo, 1997; Samper, 2001; Viales \& Montero, 2015). Before 1950 most coffee plantations were established above 800 meters and below 1,400 meters (Echeverría, 1969; Hall, 1976; Ramírez, 1996). Highland production became a hallmark of the Costa Rican coffee industry due to its crucial link with product quality. At higher altitudes acidity increases and gives a taste that has been highly valued in the international market. Indeed, altitude also determines the coffee settlement paid to producers (Samper, 2001; Viales \& Montero, 2015). This became an important feature of Costa Rican coffee specialization throughout its long history, which has prompted coffee-growers to search more for economies of scope of a high-quality product coproduced together with other goods in poly-cultural shaded coffee plantations, rather than economies of scale to compete through larger sales at lower prices.

From 1950 to 1980 coffee also expanded to some areas considered marginal, both lowlands and highlands, because of the strong institutional promotion of the GR type of management aimed at overcoming natural constraints (Aguilar, Barboza \& León, 1982; Hall, 1976; Samper, 2001; Picado, 2000; Ledezma \& Granados 2008). Yet these attempts did not go very far, as shown by the positive and significant relationship obtained in our statistical test with first-nature variables. This confirms that the altitude remained a determining factor for farmers to decide where to establish coffee plantations, although the regulated market could have also promoted the production of lower quality coffee in a period when the indicative prices per coffee group did not vary significantly, thus penalizing high over low quality production (Montero, 2018).

Coffee-growing management also varies depending on altitude. In highlands, the distance between coffee plants has to be greater because they are taller and grow slower, harvesting starts later, and the expensive task of picking the berries can become unprofitable in a greater number of years than in lower altitudes where the plant behaves inversely to 
the aspects described above (Pérez \& Pelecano, 1979). These agroclimatic conditions also change when considering other factors such as temperature and humidity, which directly influence the vegetative growth of the plant, or precipitation that has a positive effect on flowering (Charpantier, 1988). Even when coffee was confined to middle zones, other climatic elements could reach sub-optimal thresholds.

The results of the model also show a positive and significant relationship between sunshine levels (luminosity) and coffee specialization areas. The influence of luminosity on crops runs through three different components: intensity (radiation), quality, and duration (photoperiod). Coffee produces a drier product when it receives more radiation, and there is a positive correlation between leaf area index and coffee production. The higher the light intensity, the greater the production of coffee berries is. However, this also implies a crop more prone to weed growth and disease infections (Rodríguez, 1999).

After an initial phase of trial and adoption of the crop following the older Caribbean way of monoculture plantations, in Costa Rica coffee was traditionally grown mainly under agroforestry systems with regulated shade (Charpantier, 1988; Naranjo, 1997; Sfez, 2000; Samper, 2001). During the GR period there was an active institutional attempt to convince farmers to remove shade trees from coffee plantations (Picado, 2000; López \& Picado, 2012). Indeed, many agronomists had already recommended supressing the shade since the nineteenth century, arguing that the intercropped trees prevented the coffee from receiving the necessary radiation, or even that coffee bushes would shade themselves. They also considered that an excess of shade generated a moister environment that stimulated fungal diseases (Naranjo, 1997; Viales \& Montero, 2015).

These efforts failed. Despite all recommendations and pressures during the GR deployment, most small and medium-size producers decided to keep their coffee plantations under regulated shade even though this might negatively impact the quantity of production (Montero, 2018). Costa Rican family farmers also knew from their own biocultural knowledge that the secondary products and by-products of the shade trees could offset or even overcompensate for any eventual lower coffee production, while keeping the whole plantation and soil in a better agroecological state, which helped to ensure product quality and yield stability in the long run (Campbell, 2012; Iverson et al., 2014).

In Costa Rica, coffee under shade comprised, and includes, two modalities: temporary shade and permanent shade. The function of temporary shade is to reduce the luminosity, in order to protect the coffee from direct sunlight. It is made up of fast-growing plants, and these, in principle, remain only the time it takes for the permanent shade to grow. The permanent shade is usually cultivated one year before eliminating tempo- 
rary shade, and it is the type of definitive shade that regulates the entry of light into the coffee plantation. The regulated shade system requires annual maintenance, which consists of pruning (Pérez \& Pelecano, 1979: 30-1; Pérez, 1983: 22-4; Ramírez, 1986: 1-3; Rodríguez, 1999: 31-2).

Historical sources confirm that the presence of shade in Costa Rican coffee plantations continued to be maintained during the period of the greatest technological change along GR lines. Although we refer especially to the shade of service, it contributed to keep a series of ecosystem services such as temperature control, Nitrogen fixation, runoff reduction, maintenance of stable crops, increased longevity of coffee plantations, erosion control, and coffee quality maintenance (DaMatta, 2004; Rojas, Canessa \& Ramírez, 2005; Rapidel et al., 2015). In 1981, the results of a survey-sampling on coffee technology in Costa Rica concluded that $89 \%$ of the 4,300 producers surveyed were still using shade (MAG, 1981: 5). In 1992 a study carried out by the Coffee Institute of Costa Rica (ICAFE) showed that $74 \%$ of the coffee area in the country was under shade, and that the tree species most used for this purpose (38.7\% of shade trees) was a legume, the Erythrina poeppigiana usually known in the region as poró (Obando, 1995: 5; Campbell, 2012). In 2008, a nationwide study accounted for more than 262 tree and shrub species used in coffee plantations only in the Central Valley (Virgilio Filho, 2008).

Statistical results also found a positive and significant relationship between rainy days and coffee locations. As with altitude, the optimal precipitation range for coffee is quite broad, ranging from 1,200 to 2,300 mm per year (Rojas, 1987; Rodríguez, 1999). Precipitations levels above $3,000 \mathrm{~mm}$ or below $1,000 \mathrm{~mm}$ are not suitable for the plant. An excess of rain attenuates bush growth and causes the coffee berries to fall when they have formed due to poor root aeration when water saturates the soil. Conversely, water stress paralyzes growth, prevents fruits from reaching physiological maturity, and reduces production (Rodríguez, 1999).

Precipitation distribution throughout the year is another crucial agroclimatic factor for coffee growth, as it significantly affects flowering and ripening season. Coffee requires enough rainy days, such as a minimum of 145 and a maximum of 245 . They have to be distributed over a given period because the plant also requires a dry period of 3 to 4 months (Campos, 1978). Hence, the flowering of the coffee plant is highly influenced by precipitation distribution. During the rainy season, flower buds grow up to a certain point ( 4 to $5 \mathrm{~mm}$, or 7 to $8 \mathrm{~mm}$ ), but they cease to grow during the dry season when they go dormant, and they resume in response to precipitation of some magnitude. It is during these "floral rains" that the principal flowering takes place (Rojas, 1987; Rodríguez, 1999). To sum up, first and foremost, our model confirms the relevance of first-nature deter- 
minants in the Costa Rican location of coffee-growing specialization (Krugman, 1993; Cronon, 1991).

Regarding land-use variables, the results confirm a negative and significant relationship between pastures and coffee land shares. This means that when the share of the coffee surface within the UAA is higher, the share of pastures is lower (Table 4). Coffee seems to have been substitutive to pasture (surely over grazing land), and to a lesser extent to forests ${ }^{2}$. A non-significant relationship was found with sugarcane or basic grains and coffee. These results confirmed that coffee was more a supplementary crop than a substitute during the major period of technological change along GR lines (Annex 2).

Our statistical findings are consistent with the fact that during the period considered Costa Rica went through a long process of agricultural diversification. Favourable public policies, like the one implemented for coffee, were also applied to sugarcane, basic grains, and pastures for livestock rearing (Solís, 1983; Aguilar \& Solís, 1988; León \& Arroyo, 2012; León, 2012). They fostered the expansion of these cultivations and land uses in specific regions where coffee remained a complementary crop (Barrantes, Bonilla \& Ramírez, 2011). Coffee plantation did not jeopardize basic grains, either grown by subsistence or commercial farmers, nor other cash crops and agricultural activities, and not even between 1955 and 1963 when the largest coffee area expansion occurred.

Considering demographic variables, the statistical model confirms the existence of a significant relationship between population density and coffee land share in the UAA, which corroborates that coffee cropping is an activity that requires a large supply of seasonal labour during harvest and some amount of permanent workforce for the rest of the year. Despite population growth after the 1950s, the country suffered a lack of manpower that became a severe problem for the coffee industry which had to compete in the labour market with other agricultural, livestock, agro-industrial, and industrial activities. In the 1950s agriculture remained the largest employment sector, with some 130,000 workers that represented $55 \%$ of the country's economically active population (EAP). In the 1970 s -during the ISI context- agricultural EAP went down to nearly $45 \%$, but it remained quite high (León, 2012).

Historically, Costa Rican coffee production has been mainly managed by small and medium landowners, where unpaid family labour was essential to cover the permanent work needed throughout the year (Samper, 2001). However, coffee expansion also led to semi-proletarianization and proletarianization of the harvesting workforce beginning in

2. See annex 2 at https://doi.org/10.26882/histagrar.083x04m. 
the nineteenth century (Gudmundson, 1989; Molina, 2002). Despite the historically chronic lack of labour, harvesting was never mechanized, not even on large estates (haciendas). Given the existence of climatic gradients and weather oscillations during the year, berries' ripening varied along with time and altitude, forcing farms to perform various collections in order to guarantee that all of them were picked properly. Once again, the priority given to quality largely explains why farmers opted for manual harvesting.

Medium and large coffee producers had to compete for reaping labour. This was good for the harvesters, because they obtained a higher payment for each cajuela of coffee collected (1/20 of coffee bushel). In 1961 a study of the cost of coffee production per hectare pointed out that the greatest share of expenses was incurred at the harvest time (43\%). In Costa Rica, there are early maturing (Turrialba, Brunca, and Pacific) and late maturing (Central, Western, and Tarrazú) coffee regions. This allowed for seasonal regional migrations of coffee pickers. Large producers transported hired pickers from long distances to their large estates (haciendas), accommodating them during three or four months of harvest. Alternatively, small and medium coffee producers agree on sharing hired labour from the start of the harvest.

Finally, distances to ports and the capital were contemplated as market access variables (both foreign and domestic) in the model. Costa Rica has two major ports: Puerto Limón (on the Caribbean) and Puntarenas (on the Pacific). The results show a negative and important relationship between distance to Puerto Limón and coffee specialization areas, thus confirming the relevance of second-nature drivers. Coffee was from the onset a cash-crop exported to European marketplaces, and up to the mid-twentieth century Puerto Limón became the most important port on the Caribbean coast. Then, from 1950 onwards, the US became a tremendous coffee commercial partner. New York and New Orleans were the main coffee trading places, and the maritime routes from the East coast retained its important role.

During our period of analysis, and especially from the 1970s onwards, the domestic market was invigorated with ongoing changes in consumption patterns, institutional promotion, and reduction of local transport costs with the construction of the Pan-American Highway and its connection to secondary roads. Internal consumption supplemented foreign markets as a pulling force of coffee production growth, which experienced a five-fold increase from the 1950s to the 1980s (Hall, 1976; Jiménez, 2013).

Transport costs to the markets were assumed by coffee miller-exporters and traders, who concentrated the ownership of trucks. Small and medium-sized producers had to deliver coffee directly to these millers and receivers (Hall, 1976; Sfez, 2000). Up to the 1950s, 
cars, and later pickup trucks or jeeps, mainly did this job. But gradually, light cargo trucks formed part of the Costa Rican rural landscape. In 1960 pickup trucks and jeeps accounted for $19 \%$ and $16 \%$ of the vehicular fleet, respectively, and cargo trucks $19 \%$ (MOPT, 1961). The Banco Nacional granted credit for purchasing these vehicles through Rural Credit Boards (Chacón \& Montero, 2015). Not all producers could count on their transport, as it required larger capital investments, and many of them had to rely on those who were able to offer freight services during harvest.

\section{CONCLUDING REMARKS}

This paper has been focused on explaining the main determinants of Costa Rican coffee frontier advance and the geographical patterns of regional specialization in the context of the GR and coffee market regulation. Costa Rican coffee dynamics during that period responded to market demand. The growing consumption, both domestic and foreign, prompted modernization of the sector and pushed the advance of the coffee-growing frontier towards new specialization areas, as seen in the statistically significant results of our model that show the relevance of the distance to seaports or the capital of the country. Population densities appeared also as a relevant second-nature driver of the locations where the coffee-growing frontier expanded due to their impact both on labour supply and increasing demand. This also confirms what can be inferred from the stylized facts, which suggests that favourable conjunctures in coffee prices pulled area expansion and coffee crop intensification.

Yet the dataset we have assembled, and some results of our statistical test on the variables that explain where coffee plantations were spread, and where not, also make apparent that this historical process was more complex than a simple standard model of induced innovation. As we expected, the results highlight that coffee specialization areas were always positively and significantly related to a set of agro-climatic variables (altitude, sunshine, rainy days), kept a negative and significant relationship with the pastureland area (and forestland to a lesser extent) that they replaced, and had no significant relationship with the proportion of basic grains and the rest of crops. This is also related to the fact that after the early and robust impulse of the GR in Costa Rica, all coffee-growing regions kept shaded coffee plantations within diversified cultural landscapes. Counter to the efforts devoted to monoculture propagation in that historical period, forests and pastures dominated the landscape even in regions with a more significant presence of coffee plantations. The reasons behind this agricultural land use diversification, and the resilience of shaded cropping in all Costa Rican coffee-growing regions, need to be studied in greater depth in further research (Campbell, 2012). Still, it seems that the reluctance of family 
farms to become too dependent on the success or failure of a single cash-crop could have played a role in this socioecological outcome.

The maintenance of shaded coffee cultivation was added to the option for optimal agro-climatic locations within diversified cultural landscapes. On one hand, the strong significance of agroecology determinants in choosing planting locations clearly counters the strong belief by promoters of the GR that the new breeds, agrochemicals, and management techniques were abolishing natural restrictions to crops. On the other hand, the complementary role that coffee plantations continued to play alongside with basic grains, sugarcane, pastures, and woodland speaks to the multi-purpose aims of Costa Rican rural communities where family farms predominated. Both sides of the coin entailed that agrodiversity was maintained at the plot or farm level, as well as at the landscape and regional level.

This socioecological outcome can be seen from an environmental history standpoint as an example of farmers' site-specific traditional knowledge that, in the long run, has proven to be more agro-ecologically resilient than the technocratic prescriptions of the GR which tried to offer the same ready-made solutions everywhere and for everything (Netting, 1993; Berkers, Colding \& Folke, 2000; Toledo \& Barrera-Bassols, 2008; GómezBaggethun, Corbera \& Reyes-García, 2013). This important outcome does not deny the substantial impact of the GR in Costa Rican coffee production, as shown by the replacement of traditional shade trees towards more commercial species at the expense of the organic fertilization provided by leguminous trees, and the adoption of very high doses of industrial fertilizers (Perfecto et al., 2005: Infante \& Picado, 2018).

We conclude that the Costa Rican coffee sector went through profound and evolving transformations as a result of a set of historical drivers that set in motion a wide range of regional trajectories in the territory, which turned out to be much more complex than a simple adoption of the external inputs, techniques and management prescriptions of the GR, to respond to favourable market conditions and public policies. In summary, the model we built and tested using the new dataset has been able to bring to light the role that all these geographical and historical factors played in pushing, pulling, and conditioning the coffee frontier expansion of Costa Rica during the years of the GR. Both firstnature factors (i.e., physical geography) and second-nature drivers (i.e., human geography and agency) played a role in this environmental and socioeconomic history.

We know that after attaining yields of nearly $1,700 \mathrm{~kg}$ of coffee per hectare in 198485 , a worldwide record, aggregate figures went down up to some $900 \mathrm{~kg} / \mathrm{ha}$, a level comparable to the one in 1967-71 in the country (Fig. 6). The site-specific Costa Rican fea- 
tures we have brought to light also point out that behind this trend there might have been the decision of many small coffee growers to make a selective adoption of mainstream Green Revolution management, and keep coffee growing under shade trees in order to avoid overdependence on external industrial inputs while they largely adopted industrial fertilizers at the same time. When world coffee prices went down, this strategy allowed them to recover profitability during challenging times. This behaviour deserves another more in-depth study. But if it is confirmed by future research, it would appear to be very consistent with the persistence of Costa Rica as an old coffee exporter, mainly searching for product quality differentiation. Further research is needed to study how Costa Rican coffee growers responded to the end of state-led GR promotion in the 1980s, and the abolishment of ICA market regulation in 1989 when the Cold War had come to an end (Topik \& Samper, 2006; Samper, 2010).

\section{AKNOWLEDGEMENTS}

We would like to thank the anonymous referees for their constructive contributions that greatly improved this article and also the editors of Historia Agraria. We are also extending gratefully by our colleagues Wilson Picado, Juan Infante, Vicente Pinilla and José PeresCajías for their comments, criticism and suggestions provided.

\section{REFERENCES}

Aguilar, J., Barboza, C. \& León, J. (1982). El desarrollo tecnológico del café en Costa Rica $y$ las políticas científicas tecnológicas. San José: Consejo Nacional de Investigaciones Científicas y Tecnológicas.

Aguilar, I. \& Solís, M. A. (1988). La élite ganadera en Costa Rica. San José: Universidad de Costa Rica.

BARRANTES, E., Bonilla, H. \& RAmírez, O. (2011). Las subsistencias en una coyuntura de crisis: Produccion, consumo y nivel de vida, Costa Rica, 1905-1925. San José: Universidad de Costa Rica.

Berkers, F., Colding, C. \& FolKe, C. (2000). Rediscovery of Traditional Ecological Knowledge as Adaptive Management. Ecological Applications, 10 (5), 1251-61.

BILDER, R. B. (1963). The International Coffee Agreement: A Case History in Negotiation. Law and Contemporary Problems, 28 (2), 328-91.

CAmpbell, L. (2012). Biophysical Drivers of Tree Crop Performance in Shade Agroforestry Systems:The Case of Coffee in Costa Rica. Master's thesis. Ottawa: University of Toronto. 
Campos, E. (1978). El café en Costa Rica: Información general. San José: Direccion de Investigaciones Agrícolas, Departamento de Investigaciones en Café.

Chacón, M. \& Montero, A. (2015). El Banco Nacional y el desarrollo económico de Costa Rica. San José: Imprenta Nacional.

Charpantier, F. (1988). Aspectos agroclimáticos y zonificación del cultivo del café (Coffea arabica). San José: SEPSA.

Cronon, W. (1991). Nature's Metropolis: Chicago and the Great West. NewYork:W.W. Norton and Co.

Cullather, N. (2010). The HungryWorld:America's ColdWar Battle against Poverty in Asia. Cambridge: Harvard University Press.

DaMatTA, F. (2004). Ecophysiological Constraints on the Production of Shaded and Unshaded Coffee: A Review. Field Crops Research, 86 (2-3), 99-114.

Daviron, B. \& Ponte, S. (2005). The Coffee Paradox: Global Markets, Commodity Trade and the Elusive Promise of Development. London: Zed Books.

Dirección General de Estadísticay Censos (DGEC) (1959). Censo agropecuario de 1955. San José: Imprenta Nacional.

DireCCión GENERAL de Estadísticay Censos (DGEC) (1965). Censo agropecuario de 1963. San José: Imprenta Nacional.

DireCción General de Estadísticay Censos (DGEC) (1975). Censo agropecuario de 1973. San José: Imprenta Nacional.

Dirección General de Estadísticay Censos (DGEC) (1987). Censo agropecuario de 1984. San José: Imprenta Nacional.

ECHEVERRíA, G. (1969). Recopilación, consejos y notas sobre cultivo, beneficio y torrefacción del café. San José: Texto.

FourNiER, O. (1980). Fundamentos ecológicos del cultivo de café. San José: Instituto Interamericano de Cooperación para la Agricultura.

Gómez-Baggethun. E., Corbera, E. \& Reyes-García,V. (2013). Traditional Ecological Knowledge and Global Environmental Change: Research Findings and Policy Implications. Ecology and Society: A fournal of Integrative Science for Resilience and Sustainability, 18 (4).

Gudmundson, L. (1989). Peasant, Farmer and Proletarian: Class Formation in a Smallhorder Coffee Economy, 1850-1950. Hispanic American Historical Review, 69 (2), 221-57.

Gudmunson, L. (2014). On Green Revolutions and Golden Beans: Memories and Metaphors of Costa Rican Coffee Co-op Founders. Agricultural History, 88 (4), 538-65.

Hall, C. (1976). El café y el desarrollo histórico-geográfico de Costa Rica. San José: Universidad de Costa Rica. 
Infante, J. \& Picado, W. (2018). Energy Flows in the Coffee Plantations of Costa Rica: From Traditional to Modern Systems (1935-2010). Regional Environmental Change, 18 (4), 1059-71.

Iverson, A. L., Marin, L. E., ENnis, K. K., GonthieR, D. J., ConNor-Barrie, B. T., Remfert, J. L., Cardinale, B. J. \& Perfecto, I. (2014). Do Polycultures promote WinWins or Trade-Offs in Agricultural Ecosystem Services?: A Meta-Analysis. Fournal of Applied Ecology, 51 (6), 1593-1602.

JimÉNEZ, A. (2013). El café en Costa Rica: Gran modelador del costarricense. San José: Universidad de Costa Rica.

JiMÉNEZ, M. (1995). From Plantation to Cup: Coffee and Capitalism in the United States, 1830-1930. In M. SAmPer, W. Roseberry \& L. Gudmundson (Eds.), Coffee, Society, and Power in Latin America (pp. 38-64). Baltimore: Johns Hopkins University Press.

KRUGMAN, P. (1993). First Nature, Second Nature, and Metropolitan Location. Fournal of Regional Science, 33 (2), 129-44.

Ledezma, R. A. \& Granados, R. (2008). Degradación ambiental y caficultura en Tarrazú entre 1970 y 2006. Revista de Ciencias Ambientales, 36 (2), 11-18.

LEÓN, J. (2012). Historia económica de Costa Rica en el siglo XX: La Economía Rural. San José: Universidad de Costa Rica.

LEÓN, J. \& ARroyo, N. (2012). Desarrollo histórico del sector agroindustrial de la caña de azúcar en el siglo XX: Aspectos económicos, institucionales y tecnológicos. San José: Universidad de Costa Rica/Instituto de Investigaciones en Ciencias Economicas.

LópeZ, M. \& PiCADO, W. (2012). Plantas, fertilizantes y transición energética en la caficultura contemporánea de Costa Rica: Bases para una discusión. Revista de Historia, (65-66), 17-51.

Molina, I. (2002). Costa Rica (1800-1850): El legado colonial y la génesis del capitalismo. San José: Universidad de Costa Rica.

Montero, A. (2018). Café, Revolución Verde, regulación y liberalización del mercado: Costa Rica (1950-2017). PhD thesis. Barcelona: Universidad de Barcelona.

Ministerio de Agricultura y Ganadería (MAG) (1954, 1955, 1957, 1959, 1967, 1968, 1969, 1970, 1971, 1972, 1979, 1980, 1981, 1985, 1986). Memorias del MAG. San José: Imprenta Nacional.

Ministerio de Agricultura y Ganadería (MAG) (1968). Estudios de costos de producción de café: Plan Cooperativo MAG/ICAFE. San José: Imprenta Nacional.

Ministerio de Agricultura y Ganadería (MAG) (1981). Datos de la encuesta-muestreo sobre la tecnología de café en Costa Rica. San José: Imprenta Nacional.

McCook, S. (2009). La Roya del café en Costa Rica: Epidemias, innovación y medio ambiente, 1950-1995. Revista de Historia, (59-60), 99-117.

McCook, S. (2017). Environmental History of Coffee in Latin America. In Oxford Research Encyclopedia of Latin American History. 
Ministerio de Obras Públicas y Transportes (MOPT) (1961). Vehículos automotores en circulación en Costa Rica al 31 de diciembre de 1960. San José: MOPT.

Moguel, P. \& Toledo, V. M. (1999). Biodiversity Conservation in Traditional Coffee Systems of Mexico. Conservation Biology, 13 (1), 11-21.

NARANJo, C. (1997). La primera modernización de la caficultura costarricense (18901950). Master's thesis. San José: Universidad de Costa Rica.

Netting, R. M. (1993). Smallholders, Householders: Farm Families and the Ecology of Intensive, Sustainable Agriculture. Stanford: Stanford University Press.

Obando, J. J. (1995). Métodos de propagación de Erythrinas sp (poró). Noticiero del Café, $10(89), 5$.

Oficina de Planificación Nacional y Política Económica (OFIPLAN) (1979). Plan Nacional de Política Cafetalera. San José: OPSA.

Patel, R. (2013). The Long Green Revolution. The fournal of Peasant Studies, 40 (1), 1-63.

PÉREZ, V. M. (1983). Treinta y dos años de investigación sistemática y transferencia tecnológica del cultivo de café en Costa Rica, 1950-1952. San José: Oficina del Café de Costa Rica.

Pérez, V. M. \& Pelecano, J. A. (1979). Guía práctica del cultivo del café: Especies y variedades, establecimiento y renovación. San José: CAFESA.

Perfecto, I. \& VAndermeer, J. (1994). Understanding Biodiversity Loss in Agroecosystems: Reduction of Ant Diversity Resulting from Transformation of the Coffee Ecosystem in Costa Rica. Entomology, (2), 7-13.

Perfecto, I., Vandermeer, J., Mas, A. \& Pinto, L. S. (2005). Biodiversity, Yield, and Shade Coffee Certification. Ecological Economics, 54 (4), 435-46.

Perfecto, I., Vandermeer, J. \& Philpott, S. M. (2014). Complex Ecological Interactions in the Coffee Agroecosystem. Annual Review of Ecology, Evolution, and Systematics, (45), 137-58.

PiCADo, W. (2000). La expansión del café y el cambio tecnológico desigual en la agricultura del cantón de Tarrazú. Master's thesis. Heredia: Universidad Nacional Costa Rica.

Picado, W. (2012). En busca de la genética guerrera: Segunda Guerra Mundial, cooperación agrícola y Revolución Verde en la agricultura de Costa Rica. Revista de Historia Agraria, (56), 107-34.

PICADO, W. (2014). Los significados de la revolución: Semántica, temporalidad y narrativa de la Revolución Verde. Historia Ambiental Latinoamericana y Caribeña, 3 (2), 490-521.

Picado, W., Ledezma, R. \& Granados, R. (2009). Territorio de coyotes, agroecosistemas y cambio tecnológico en una región cafetalera de Costa Rica. Revista de Historia, (59-60), 119-65.

Ponte, S. (2001). The "Latte Revolution"?: Winners and Losers in the Restructuring of the Global Coffee Marketing Chain. CDR Working Paper, (13). 
Ponte, S. (2002). The "Latte Revolution"? Regulation, Markets and Consumption in the Global Coffee Chain. World Development, 30 (7), 1099-122.

RAmírez Rojas, J. (1986). El uso de la sombra en plantaciones de café en la zona de Pérez Zeledón. Noticiero del Café, (8), 1-3.

Ramírez Rojas, J. (1996). Poda y manejo del Coffea arabica L. San José: ICAFE.

Rapidel, B., Allinne, C., Cerdán, C., Meylan, L., Filho, E. D. M. V. \& Avelino, J. (2015). Sistemas Agroforestales (5). In F. MonTAGnini et al. (Eds.), Sistemas agroforestales, funciones productivas, socioeconómicas y ambientales. Turrialba: CATIE.

RAVENTós, C. (1986). Desarrollo económico, estructura y contradicciones sociales en la producción de café. Revista de Historia, (14), 179-95.

Rice, R. A. (1999). A Place Unbecoming: The Coffee Farm of Northern Latin America. Geographical Review, 89 (4), 554-79.

RodrígueZ, A. (1999). Cultivo del café: Material didáctico para el instructor(a). San José: INA.

Rojas, F., Canessa, R. \& Ramírez, J. (2005). Cafetales arbolados. Revista Forestal Mesoamericana Kurú, 2 (4), 101-6.

Rojas, O. (1987). Zonificación agroecológica para el cultivo del café (Coffea arabica) en Costa Rica. San José: IICA.

SAmper, M. (Ed.) (2001). La cadena de producción y comercialización del café: Perspectiva histórica y comparada. San José: Progreso.

Samper, M. (2010). Costa Rica's Response to the Coffee Crisis. Latin American Perspectives, 37 (2), 72-92.

SFEZ, P. (1995). La evolución de un frente de colonización agrícola y el desarrollo de una caficultura altamente competitiva. Revista de Historia, (3), 175-214.

SFEZ, P. (2000). Revolución Verde y cambio tecnológico en la caficultura. In M. SAMPER, C. NARANJo \& P. SFEZ, Entre la tradición y el cambio: Evolución tecnológica de la caficultura costarricense (pp. 59-76). San José: Universidad Nacional.

Solís, M. (1983). La elite ganadera en Costa Rica, su importancia y su inserción en la economía nacional. San José: Instituto de Investigaciones Sociales.

Swaminathan, M. S. \& Kesavan, P. C. (2017). The Transition from Green to Evergreen Revolution. Historical Perspectives, (69), 70-6.

Tilley, D. S. \& Indahsari, G. K. (1996). Impact of International Coffee Agreement Abandonment on Indonesian Coffee Prices, Agribusiness, 12 (2), 157-66.

Toledo, V. M. \& BARRERA-BAssols, N. (2008). La memoria biocultural: La importancia ecológica de las sabidurías tradicionales. Barcelona: Icaria.

TopiK, S. \& SAmper, M. (2006). The Latin American Coffee Commodity Chain: Brazil and Costa Rica. In S. TopiK, C. MARICHAL \& Z. Frank (Eds.), From Silver to Cocaine: Latin America Commodity Chains and the Building of the World Economy, 1500-2000 (pp. 118-46). Durham: Duke University Press. 
VARGAS, E. (1986). Certificación de semilla y almácigo: Programa innovador y singular en países latinoamericanos productores de café. Noticiero del Café, 1 (7), 3-4.

Viales, R. \& Montero, A. (2015). La construcción de la calidad del café y del banano en Costa Rica: Una perspectiva histórica (1890-1950). Historia Agraria, (66), 147-76.

Vidal Luna, F., Klein, H. S. \& Summerhill, W. (2016). The Characteristics of Coffee Production and Agriculture in the State of São Paulo in 1905. Agricultural History, 90 (1), 22-50. https://www.jstor.org/stable/10.3098/ah.2016.090.1.22

Virgilio FilHo, E. M. (2008). Diversidad arbórea y arbustiva: La riqueza escondida en los cafetales de Costa Rica. San José: CATIE/ICAFE.

Winson, A. (1989). Coffee and Democracy in Modern Costa Rica. London: Palgrave Macmillan. 


\section{ANNEX 1}

\section{Costa Rican coffee regions and their main geo-historical features}

\begin{tabular}{|c|c|c|c|}
\hline $\begin{array}{c}\text { Coffee } \\
\text { regions }\end{array}$ & $\begin{array}{c}\text { Beginning } \\
\text { of coffee-growing }\end{array}$ & $\begin{array}{c}\text { Agro-ecological } \\
\text { conditions }\end{array}$ & Population \\
\hline $\begin{array}{l}\text { Central } \\
\text { Region }\end{array}$ & $\begin{array}{l}\text { Early of the } 19^{\text {th }} \\
\text { century }\end{array}$ & $\begin{array}{l}\text { Altitude: } 800-1600 \\
\text { Temperature: } 18-24^{\circ} \mathrm{C} \\
\text { Rainfall: } 1500-2000 \mathrm{~mm} \\
\text { Seasons: dry (May-November) } \\
\text { rainy (December-April) } \\
\text { Soils: mainly volcanic }\end{array}$ & $\begin{array}{l}\text { From the colonial pe- } \\
\text { riod, it concentrates the } \\
\text { major population of the } \\
\text { country. }\end{array}$ \\
\hline $\begin{array}{l}\text { Western } \\
\text { Region }\end{array}$ & $\begin{array}{l}\text { Second half of the } \\
19^{\text {th }} \text { century and se- } \\
\text { cond half of the } 20^{\text {th }} \\
\text { century }\end{array}$ & $\begin{array}{l}\text { Altitude: } 600-1500 \\
\text { Temperature: } 21-26^{\circ} \mathrm{C} \\
\text { Rainfall: } 1000-2000 \mathrm{~mm} \\
\text { Seasons: dry (May-November) } \\
\text { rainy (December-April) } \\
\text { Soils: volcanic and lateritic }\end{array}$ & $\begin{array}{l}\text { Initially populated by } \\
\text { migrations from the } \\
\text { Central Plateau }\end{array}$ \\
\hline
\end{tabular}

\begin{tabular}{|c|c|c|c|}
\hline \multirow{6}{*}{$\begin{array}{l}\text { Tarrazú } \\
\text { Region } \\
\text { (TAR) }\end{array}$} & \multirow{6}{*}{$\begin{array}{l}\text { Second half of the } \\
19^{\text {th }} \text { century and se- } \\
\text { cond half of the } 20^{\text {th }} \\
\text { century }\end{array}$} & Altitude: $800-1900$ & \multirow{5}{*}{$\begin{array}{l}\text { Initially populated by } \\
\text { migrations of the west of } \\
\text { San José (capital) }\end{array}$} \\
\hline & & Temperature: 18 y $23^{\circ} \mathrm{C}$ & \\
\hline & & Rainfall: 2200 y $3000 \mathrm{~mm}$ & \\
\hline & & Seasons: dry (May-November) & \\
\hline & & rainy (December-April) & \\
\hline & & Soils: sedimentary & \\
\hline
\end{tabular}

Altitude: 600-1400

Temperature: $24-27^{\circ} \mathrm{C}$

Turrialba At the end of the

Rainfall: 2000-4000

By migration of the

Region $19^{\text {th }}$ century

Season: rainy all year

Central Plateau

Soils: alluvial and volcanic

\begin{tabular}{llll}
\hline & $\begin{array}{l}\text { At the end of the } \\
19^{\text {th }} \text { century but } \\
\text { mainly in the second } \\
\text { half of the } 20^{\text {th }} \text { cen- }\end{array}$ & $\begin{array}{l}\text { Altitude: } 100-3800 \mathrm{~m} \\
\text { Temperature: } 18-32{ }^{\circ} \mathrm{C}\end{array}$ & $\begin{array}{l}\text { Rainfall: } 2000-4000 \mathrm{~mm} \\
\text { tury }\end{array}$
\end{tabular}

At the end of the

$\begin{array}{lll}\text { Pacific } & \begin{array}{l}19^{\text {th }} \text { century but } \\ \text { mainly in the second }\end{array} & \text { Altitude: } 100-800 \mathrm{~m} \\ \text { Ralf of the } 20^{\text {th }} \text { cen- } & \text { Temperature: } 27 \text { y } 32^{\circ} \mathrm{C} \\ \text { tury } & \begin{array}{l}\text { Rainfall: } 2000 \text { y } 4000 \mathrm{~mm} \\ \text { Soils: alluvial and volcanic }\end{array}\end{array}$

By migration of the

Central Plateau and other regions 


\section{ANNEX 2}

Explaining Costa Rican coffee specialization determinants

Supplementary material

\section{ANNEX 3}

New dataset on the scope of the Costa Rican Utilized Agricultural Area and the proportion of crops by region

Supplementary material

(See annex 2 and 3 at https://doi.org/10.26882/histagrar.083x04m.). 